\title{
ANALYSIS OF ORGANIZATIONAL PERFORMANCE THROUGH TRANSFORMATIONAL LEADERSHIP AND ORGANIZATIONAL CULTURE
}

\author{
Sukmo Hadi Nugroho ${ }^{1}$, Elisabeth Tanti Pudiastuti ${ }^{2}$ \\ 1 Universitas Esa Unggul, Jakarta Indonesia \\ 2 Sekolah Tinggi Manajemen STIMA IMMI, Jakarta Indonesia
}

\begin{abstract}
Organizational performance plays an important role as a measure of the success of an organization or company. To achieve this success, organizational performance is influenced by many factors, including transformational leadership and organizational culture itself. The purpose of this study was to determine the effect of these two factors on organizational performance. The population of this research is all employees in a company of 94 people with the sampling technique using the total sample. Based on data processing with the SPSS Version 19.00 statistical program, it proves that partial hypothesis testing for transformational leadership and organizational culture variables is proven to affect organizational performance, this explains that the better the leadership and organizational culture are implemented, the more it can improve organizational performance. independent of organizational performance can be seen in the value of $R$ Square of $33.1 \%$ and the rest is influenced by other variables not examined in this study. This shows that leadership and organizational culture have an important role for success in motivating employee work, which ultimately has an impact on organizational performance.
\end{abstract}

Keyword: Organizational Performance, Transformational Leadership, Organizational Culture

\section{INTRODUCTION}

Competition in the business world today demands that workers are better prepared to face the challenges that lie ahead. For the company to continue to exist, it must be brave in facing the challenges and their implications, namely facing change and winning the competition. Resources owned by companies such as capital, methods, and machines cannot provide optimum results if they are not supported by human resources who have optimum performance (Rani 2009). The success of an organization is also determined by the leadership developed in that organization, and high employee commitment to the organization can bring the organization to achieve the expected goals. Locke (1997 in Harsiwi, 2003) describes leadership as a process of inducing (inducing) other people towards common goals. This definition includes three elements, namely, Leadership is a relational concept, leadership is a process and leadership must persuade other people to take action.

An employee is considered productive if he can produce work activities that comply with the standards set by the company. The determinants that influence the achievement of a high level of productivity by an employee include the commitment and performance of the employee to the organization they oversee. Therefore, to maintain and increase organizational commitment and employee performance, companies are expected to pay attention to transformational leadership and organizational culture in the company.
Transformational leadership that conditions assumptions, norms, and values do not prevent employees from pursuing the goals and benefits of employees, even with transformational leadership can encourage employees to work harder (Chen, 2004). Because with the changes that occur in the organization, employees will be motivated to work hard to achieve the goals expected by the organization. Real leaders must be able to direct the organization towards new directions (Locke, in Harsiwi, 2003). Transformational leadership is expected to motivate subordinates to work more actively so that they can achieve the desired organizational goals.

Organizational culture and leadership have been independently linked with company performance. Researchers have tested the relationship between leadership style and performance (Bass et.al, 1993 in Rani, 2009) and also between corporate culture and performance (Abdul Rashid et.al, 2003 in Rani, 2009). Bass and Avolio (1993) and Schein (2004) in Nurjanah (2008) state that a leader forms a culture and in turn is formed by the resulting culture. Organizational culture can influence a person in shaping personality and achieving goals, responsibilities, and potential resources. human owned. Organizational culture can be a positive and negative force, thinking in making decisions in achieving organizational achievements in the form of acceptance, feelings, and actions.

Many experts say that organizational culture can be the basis for adaptation and the key to organizational success so that many 
studies are carried out to identify values or behavioral norms that can make a major contribution to organizational success (Abdul Rashid et.al, 2003 in Rani 2009). However, relatively few try to connect organizational culture with important human resource variables, particularly employee performance (Pool 2000, in Rani 2009).

Performance according to Winardi (1992 in Puspita, 2008) is a universal concept that is the operational effectiveness of an organization, part of the organization, and part of its employees based on predetermined standards and criteria, because organizations are run by humans in playing the roles they do. within an organization to meet a predetermined standard of behavior to produce the desired action and results. One indicator of the standard of behavior in performance is the discipline in attendance because attendance proves the action of an employee's work commitment.

The absence or tardiness of employees in work can also affect the level of employee performance, based on the work standards set in the Work Management System of the company, actual conditions are not following the normal conditions expected by the company. It can be explained that if an employee is absent or late for work, the tasks assigned to him will be neglected or not as expected. And this will lead to a person's ineffectiveness at work, further a decrease in performance. In the long term, this will have an impact on organizational performance. Leave from work is the right of every employee given by the organization, but if the leave is done too long it will also have an impact on employee performance.

Therefore it is necessary to have a transformational leadership style or attitude that is suitable for other situations, and also so that a good organizational culture can always be maintained, and eliminates bad organizational cultures. The problem in this study is to explain how the influence of transformational leadership and organizational culture affects organizational performance. The purpose of this study was to determine the effect of transformational leadership and organizational culture on organizational performance.

\section{MATERIALS AND METHODS Organizational Performance}

The term performance comes from the word job performance or actual performance which means the actual work performance or achievement achieved by someone. Usually, people with high performance are called productive people, and conversely, people whose performance levels do not reach the standard are said to be unproductive or lowperforming people. According to Selamet (2009) Work performance or performance (Performance management system) is a process used to identify, encourage, measure, evaluate, improve and reward employee performance. Performance is human behavior in playing the role they do in an organization to meet a predetermined standard of behavior to produce the desired action and results.

The thinking of employee performance according to Mangkunegara (2005) is the result of work in quality and quantity achieved by an employee in carrying out his duties following the responsibilities assigned to him. Employee performance is the result of a certain planned work process at the time and place of the employee and the organization concerned according to Mangkuprawira and Hubei (2007). Based on the description that has been stated, employee performance is the employee's contribution or the result of the work process to the organization.

The success or failure of the performance achieved by an organization is influenced by the level of performance of the employees, both individually and as a group. With the assumption that the better the employee's performance, the better the organizational performance is expected. In connection with this, in this study the approach to measuring the extent to which individual employee performance has 6 criteria, namely (Bernardin, in Robbins, 1996), namely:

1. Quality, the level at which the desired activity results are close to perfect in the sense of adjusting some ideal way of performing activities, as well as meeting the expected goals of the activity. The quality of work is measured by employees' perceptions of the quality of work produced and the perfection of tasks on the skills and abilities of employees.

2. Quantity, is the amount produced expressed in terms such as the number of units, the number of activity cycles completed. The quantity is measured from employees' perceptions of the number of activities assigned and their results.

3. Timeliness, the level of an activity completed at the stated start, seen from the point of coordination with the output results and maximizing the time available for other activities. Timeliness is measured from employees' perceptions of an activity completed at the beginning of time until it becomes the output.

4. Effectiveness, the level of use of organizational resources (manpower, money, technology, raw materials) is maximized to increase the yield of each unit in the use of resources. The effectiveness of employees' perceptions of work in assessing the use of time in carrying out tasks, the effectiveness of completing tasks that the 
organization has to do.

5. Independence, is the level of an employee who can perform his job function without asking for help, guidance from others or supervisors. Independence can be measured from employees' perceptions of duties in carrying out their respective work functions according to the employee's responsibilities.

6. Work commitment, is the level where employees have a work commitment to the agency and employee responsibilities to the office. Measurement using employee perceptions in fostering relationships with agencies as well as employee responsibility and loyalty.

\section{Performance Assessment}

If a company just holds on to the assumption that people will not work unless they are closely monitored and controlled, it tends to adopt an objective way of judgment. Therefore, reports on employee performance are confidential reports. Conversely, if the company has the view that each individual will work according to his potential and strengths and that human capabilities can be added or developed, the company will seek a system of assessment that seeks to identify, clarify, develop and utilize the potential and abilities of the employees (Rivai, 2004).

Performance Appraisal according to Slamet (2009) is a process of evaluating how well a worker does their job when compared to a standard then communicating it to workers. In an organization, assessing an employee's job is one of the manager's duties. Assessing the performance of an employee cannot get accurate results, because the nature and method of performance appraisal depend on how human resources are viewed and treated in the company.

According to Soeprihanto (1998, in Puspita, 2008) Performance Benefits The contribution of assessment results is very useful for planning organizational policies while in detail the performance assessment for organizations is: 1) compensation adjustments, 2) performance improvement, 3) needs training and development, 4) Making decisions in terms of placement of promotions, transfers, dismissals, dismissals and workforce planning, 5) For the benefit of employee research, 6) Assisting in diagnosing employee design errors.

\section{Transformational Leadership}

Robbins (2006) defines transformational leadership, namely, leaders who inspire their followers to put their interests aside for the good of the organization and they can have a tremendous influence on their followers. Transformational leadership is a leader who motivates employees to work hard to achieve higher goals (Sunarto, 2005, in Dwi, 2008). The leadership style shown by a transformational leader is expected to increase the efforts of subordinates to achieve optimal work results, where transformational leadership style is one of the leadership styles that has begun to be calculated for its use in dealing with organizational changes (Mujiasih and Hadi, 2003, in Dwi, 2008 ).

Transformational leadership is a leadership style practiced by a manager when he wants a group to widen its boundaries and have the performance beyond the status quo or achieve an entirely new set of organizational goals. In principle, transformational leadership motivates subordinates to do better than what can be done, in other words, it can increase the confidence or self-confidence of subordinates which will affect performance improvement (O'Leary in Dwi, 2008). Transformational leadership motivates employees to do work or tasks better than what subordinates want and even higher than what was previously thought. According to Hartanto, leadership like this will form the beginning to raise awareness and high commitment from the group to the goals and mission of the organization and will improve organizational performance following the achievement of company goals.

Bass (in Stefanus 2007) suggests several dimensions of transformational leadership, namely: 1. Individualized influence through rule models for followers, where followers identify and want to go beyond that model. Leaders display high standards of moral and ethical behavior and use abilities to mobilize individuals and groups towards the achievement of their mission and not for personal values.

2. Inspirational motivation, leaders provide meaning and challenge to followers to raise enthusiasm and expectations, spread vision, commitment to goals, and team support.

3. Intellectual stimulation, transformational leaders create stimulation and innovative thinking for followers through question assumptions, redesigning problems, using approaches to past situations in new ways.

4. Individualized consideration through assisting a leader, providing services as a mentor, examining individual development needs, and increasing success.

Thus the leader plays an important and much-needed role, both by the company and by subordinates. The leadership is the party that determines and the most important decisionmakers related to company policy. Transformational leadership can also change their organizational culture with a new vision and revision of the values, conditions, assumptions, and norms (Bass, 1985, in Chen, 2004). In transformational cultures, there is generally a sense of purpose and a sense of belonging. The boss feels a personal obligation to help new 
members assimilate into the culture. Assumptions, norms and values do not deter individuals from pursuing their own goals and benefits. The leader and his followers share a common interest and there is a sense of fate and dependence.

That way, the indicators of transformational leadership are charisma, inspirational motivation, intellectual simulations, individual consideration. By referring to the basic theory of Transformational leadership that contributes to organizational performance, the hypothesis proposed is

\section{H1: Transformational leadership affects Organizational Performance}

\section{Organizational culture}

Organizational culture is the most critical factor in organizations. Organizational effectiveness can be increased by creating a strong culture, which can be used to achieve organizational goals. A strong cultured organization will have certain characteristics so that it can attract individuals to join. A strong culture is a very useful tool for directing behavior because it helps employees to do their job better so that every employee needs to understand the culture and how that culture is implemented (Nurjanah, 2008).

According to Griffin and Ebbert (1996) from the quote from Umar Nimran in Eko (2009), organizational culture can be interpreted as "experience, history, beliefs and shared norms that characterize a company or organization". Organizational culture is a unique system of values, beliefs, and norms shared by members of an organization (Gibson et al, 1996, in Eko, 2009). Hofstede (1994) organizational culture is a pattern of thoughts, feelings, and actions of a social group, which differentiates it from other social groups.

Kottler and Haskett (1992) state that culture in an organization is a value shared by members of the organization, which tends to shape group behavior. Values as an organizational culture tend to be invisible so they are difficult to change. Visible norms of group behavior are reflected in the behavior patterns and styles of organizational members that can relatively change.

"Organizational culture is a factor that can improve performance", Chatman and Bersade (1997) and Udan Bintoro (2002) in Guestina (2007) state that a strong organizational culture can improve organizational performance. The organizational culture created by the leader will affect strategic applications and company success as well as employee performance.

From the above understanding, it can be concluded that organizational culture can influence a person in shaping one's personality and achieving goals, responsibilities, and potential resources. Organizational culture can be a positive and negative force, thinking in making decisions in achieving organizational achievements in the form of acceptance, feelings, and actions.

\section{Dimensions of Organizational Cultures}

Luthans (1998 in Sopiah, 2008) mentions several important characteristics of organizational culture, which include: First, rules of behavior such as language, terminology, and rituals commonly used by organizational members. Second, norms are standards of behavior that include instructions on how to do something. Furthermore, in society, we are familiar with religious norms, social norms, moral norms, customary norms. Third, dominant values such as the value expected from the organization to be carried out by members, for example, high product quality, low absenteeism, high productivity and efficiency, and high work discipline. Fourth, the philosophy that the organization believes in policies about things that employees and customers like, such as "your satisfaction is our hope", "the consumer is king. Fifth, the rules are strict rules of the organization. New employees must learn these rules to be accepted in the organization. Sixth, the organizational climate is the overall "feeling" that includes physical things, how members interact and how members of the organization control themselves in dealing with customers or parties outside the organization.

Seven dimensions are the essence of organizational culture according to Robbin (2006), namely:

1. Innovation and the courage to take risks, meaning the extent to which employees are encouraged to be innovative and take risks.

2. Attention to detail, meaning the extent to which employees are expected to demonstrate accuracy, analysis, and attention to detail.

3. Results orientation, meaning the extent to which management focuses on results rather than on the techniques and processes used to achieve these results.

4. People orientation, meaning the extent to which management decisions take into account the effect of results on humans in the organization.

5. Team orientation, meaning the extent to which work activities are organized based on a team, not on an individual basis.

6. Aggressiveness, meaning the extent to which people are aggressive and competitive rather than relaxed.

7. Stability, meaning the extent to which organizational activities emphasize maintaining the status quo in comparison with growth.

Thus organizational culture is a value system that is acquired and developed by an organization that has existed since the organization was formed and becomes a rule that is used as a guide in thinking and acting in achieving organizational goals. In research 
Gustina (2007) proves Robin's (2006) opinion that there is an influence of organizational culture variables on employee performance. Likewise, Udan Bintoro's research (2002) states that a strong organizational culture can improve organizational performance through indicators of organizational culture, namely innovation and courage to take risks, attention to detail, result orientation, people orientation, team orientation, aggressiveness, and stability. Referring to the relationship between these theories, the proposed hypothesis is:

\section{H2: Organizational culture affects organizational performance}

By looking at the relationship between transformational leadership and organizational culture on organizational performance, a research thinking model can be described as in Figure 1.

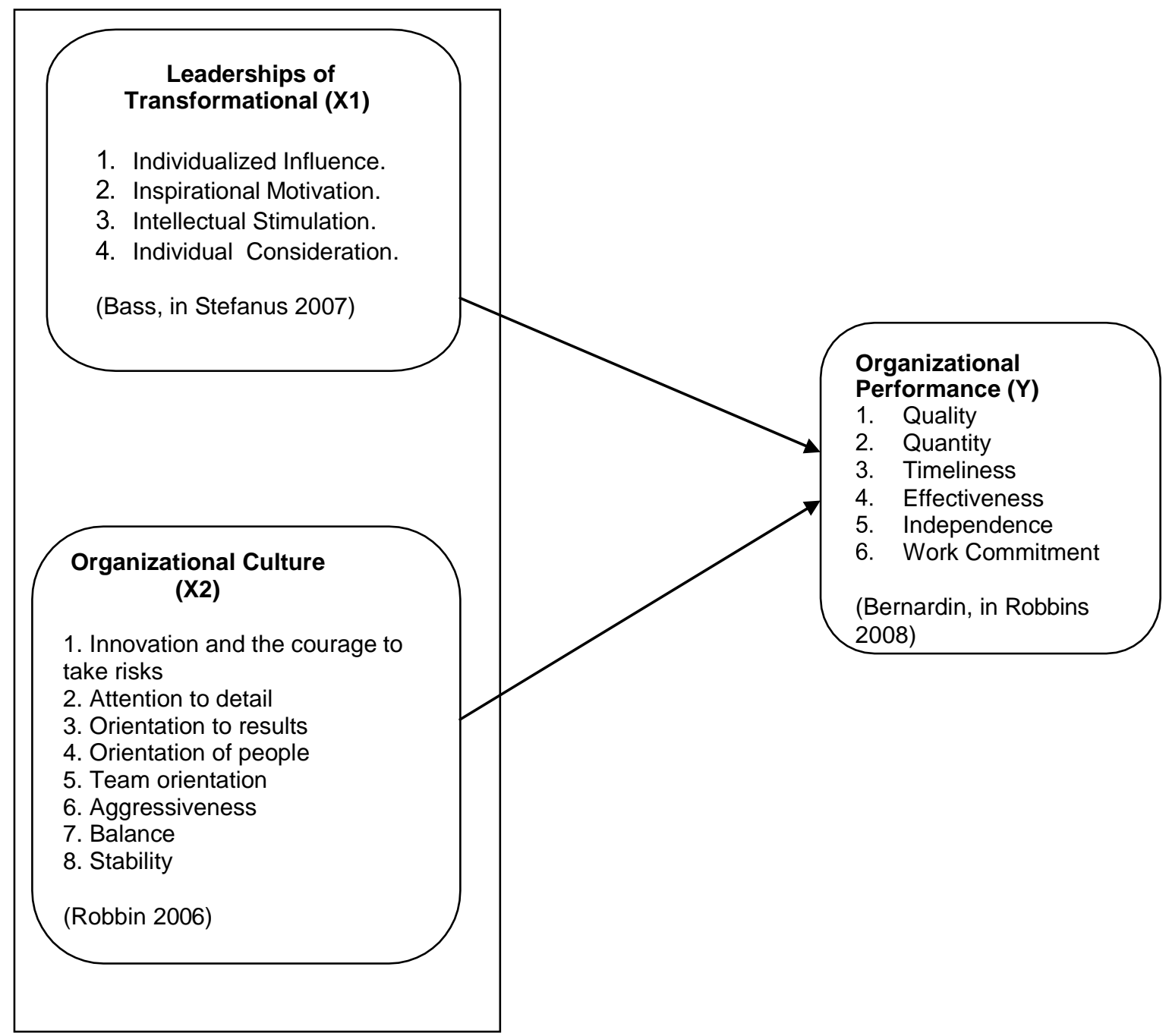

Figure 1. Research Model Constellation

\section{Research Methods}

The population of this study was all employees at a company, namely 94 people. With the sampling technique using total sampling, namely, the entire population becomes members who will be analyzed as a sample. Primary data in this study are the results of respondents' answers to the questionnaire on transformational leadership variables, organizational culture, and employee performance. Secondary data in this study is a list of reports in the form of the number of company employees, company history, and organizational structure.

Methods of data collection using documentation data in the form of names and number of staff, job descriptions and authorities, attendance data, and so on required, which are in the Company environment and data from respondents' answers from the questionnaire given. Alternative answers have been provided and it only takes a shorter time to answer them. To measure the results of respondents' responses, a scale is used. The scale used in this study is a Likert scale, where answers that support the questions are given a high score while those that are not or less supportive are given a low score.

The variables in this study include 
transformational leadership variables with indicators of Charismatic, Inspirational Motivation, Intellectual Stimulation, and Individual Considerations (Bass, in Stefanus 2007). The organizational culture variable is supported by indicators of innovation and courage to take risks, attention to detail, orientation to results, the orientation of people. Aggressiveness, and Stability. And for organizational performance variables are supported by indicators of Quality, Quantity, Timeliness, Effectiveness, Independence, and Work Commitment.

\section{RESULT AND DISCUSSION}

The results of testing the validity of 33 research instruments with the SPSS program. Version 19.00 can be seen in the following Table:

Table 1.Validity Test Results of Transformational Leadership Variables

\begin{tabular}{cccc}
\hline $\begin{array}{c}\text { Code of } \\
\text { Question }\end{array}$ & R count & R table & Result \\
\hline P1 & 0,549 & 0,444 & Valid \\
P2 & 0,591 & 0,444 & Valid \\
P3 & 0,595 & 0,444 & Valid \\
P4 & 0,527 & 0,444 & Valid \\
P5 & 0,603 & 0,444 & Valid \\
P6 & 0,772 & 0,444 & Valid \\
P7 & 0,620 & 0,444 & Valid \\
P8 & 0,638 & 0,444 & Valid \\
P9 & 0,521 & 0,444 & Valid
\end{tabular}

Source: Processed research data, 2020

Table 2. Validity Test Results for Transformational Leadership Variables

\begin{tabular}{cccc}
\hline $\begin{array}{c}\text { Code of } \\
\text { Question }\end{array}$ & R count & R table & Result \\
\hline P10 & 0,445 & 0,444 & Valid \\
P11 & 0,558 & 0,444 & Valid \\
P12 & 0,466 & 0,444 & Valid \\
P13 & 0,611 & 0,444 & Valid \\
P14 & 0,531 & 0,444 & Valid \\
P15 & 0,455 & 0,444 & Valid \\
P16 & 0,571 & 0,444 & Valid \\
P17 & 0,489 & 0,444 & Valid \\
P18 & 0,762 & 0,444 & Valid \\
P19 & 0,583 & 0,444 & Valid \\
P20 & 0,811 & 0,444 & Valid \\
P21 & 0,764 & 0,444 & Valid \\
P22 & 0,675 & 0,444 & Valid \\
\hline
\end{tabular}

Source: Processed research data, 2020

Table 3. Results of the Validity Test of Employee Performance Variables

\begin{tabular}{cccc}
\hline $\begin{array}{c}\text { Code of } \\
\text { Question }\end{array}$ & R count & R table & Result \\
\hline P23 & 0,544 & 0,444 & Valid \\
P23 & 0,612 & 0,444 & Valid \\
P25 & 0,580 & 0,444 & Valid \\
P26 & 0,754 & 0,444 & Valid \\
P27 & 0,521 & 0,444 & Valid \\
P28 & 0,492 & 0,444 & Valid \\
P29 & 0,661 & 0,444 & Valid \\
P30 & 0,492 & 0,444 & Valid \\
P31 & 0,704 & 0,444 & Valid \\
P32 & 0,485 & 0,444 & Valid \\
P33 & 0,754 & 0,444 & Valid \\
\hline
\end{tabular}

Source: Processed research data, 2020 
Based on the Table of the results of the validity test above, all question items from the variables of transformational leadership, organizational culture, and organizational performance are proven valid where all the values of $R$ count $>R$ table are set at 0.444 . The results of reliability testing of the transformational leadership variables, organizational culture, and organizational performance with the 19.00 version of the SPSS program can be seen in Table 4.

Table 4. Research Variable Reliability Test Results

\begin{tabular}{|c|c|c|c|}
\hline Variable & $\begin{array}{c}\text { Cronbach's } \\
\text { Alpha }\end{array}$ & $\begin{array}{c}\text { Cronbach's } \\
\text { Alpha } \\
\text { required }\end{array}$ & Result \\
\hline $\begin{array}{l}\text { Leadership } \\
\text { Transformational }\end{array}$ & 0,867 & 0,60 & Reliable \\
\hline $\begin{array}{l}\text { Organizational } \\
\text { culture }\end{array}$ & 0,879 & 0,60 & Reliable \\
\hline $\begin{array}{l}\text { Organizational } \\
\text { Performance }\end{array}$ & 0,879 & 0,60 & Reliable \\
\hline
\end{tabular}

Source: Processed research data, 2020

Based on the results of the reliability test, it shows that all research variables such as the variable of transformational leadership, organizational culture, and organizational performance are proven reliable, where the Cronbach's Alpha value> Cronbach's alpha is set at 0.60 . Based on the results of the regression test with the SPSS program, it can be seen as in Table 5 below:

Table 5. Results of Regression Analysis

\begin{tabular}{|c|c|c|c|c|c|}
\hline \multirow[t]{2}{*}{ Model } & \multicolumn{2}{|c|}{$\begin{array}{l}\text { Unstandardized } \\
\text { Coefficients }\end{array}$} & \multirow{2}{*}{$\begin{array}{l}\text { Standardized } \\
\text { Coefficients } \\
\text { Beta }\end{array}$} & \multirow[t]{2}{*}{$t$} & \multirow[t]{2}{*}{ Sig } \\
\hline & B & Std.Error & & & \\
\hline (Constant) & 13.952 & 4.970 & & 2.807 & .006 \\
\hline Leaderships & .204 & 0.82 & .240 & 2.489 & .015 \\
\hline Transformation & .185 & 0.86 & .215 & 2.146 & .035 \\
\hline
\end{tabular}

Organizatioal Culture

\section{Dependent Variable: Organizational Performance}

Judging from the results of the multiple regression analysis above, the following regression equation can be made $Y=13,952+0.204 X 1+$ $0.185 \times 2$. These results indicate that each value of the research variable shows a positive direction, this means that any increase in the transformational leadership variable and organizational culture will be followed by an increase in organizational performance.

Meanwhile, for testing the hypothesis it can be seen that the $t$ value of the transformational leadership variable is 2.489 with a significance value of $0.015<0.05$, this means that the hypothesis which states that transformational leadership affects organizational performance is accepted. The acceptance of this hypothesis can be explained that transformational leadership motivates employees to do work or tasks better than what subordinates want. If in an organization there is a transformational leadership style, employees will certainly be motivated to work better so that maximum results will be achieved.
This illustrates that employees feel that the leader has played their duties appropriately, both in terms of charismatic leadership, capable of providing motivation and inspiration, providing support and attention to all employees. These results support the findings of Stefanus (2007) which prove that transformational leadership can affect employee performance.

Likewise, for testing the hypothesis of organizational culture variables, it is known that the $t$ value of 2.146 with a significance value of 0.035 $<0.05$ means that the hypothesis that organizational culture affects organizational performance is accepted. The acceptance of this hypothesis can be explained that employees feel that the existing culture in the company can encourage them to be innovative in taking the risks they face, namely by contributing ideas in meetings, daring to accept challenges for new assignments that have never been accepted before, correcting work results. what they have done, and employees are always on time in carrying out their duties and come to the office on time or arrive early. These results are consistent 
with the results of Robin's (2006) research which proves that organizational culture has a direct effect on organizational performance.

The contribution of the two variables (Transformational Leadership and Organizational
Culture) to the Organizational Performance variable can be seen in the table of the coefficient of determination as in Table 6.

Table 6. Results of the coefficient of determination

\begin{tabular}{cccccc}
\hline Model & $\mathrm{R}$ & $\begin{array}{c}\mathrm{R} \\
\text { Square }\end{array}$ & $\begin{array}{c}\text { Adjusted } \\
\mathrm{R} \\
\text { Square }\end{array}$ & $\begin{array}{c}\text { Stad Error Of } \\
\text { the Estimated }\end{array}$ & $\begin{array}{c}\text { Change } \\
\text { Statistic }\end{array}$ \\
\hline 1 & $.558^{\mathrm{a}}$ & .331 & .296 & 2.39426 & .000 \\
\hline
\end{tabular}

a. Predictors: (Constant) Organizational Culture, Transformational Leadership

b. Dependent Variable: Organizational Performance

From this table, it can be explained that it is proven that the $\mathrm{R}$ Square value is 0.331 or $33.1 \%$, which means that transformational leadership and organizational culture variables have contributed to the organizational performance by $33.1 \%$, the remaining $66.9 \%$ is influenced by other variables not examined in this study.

\section{CONCLUSION}

Based on the results of research and discussion, it can be concluded that transformational leadership influences organizational performance, meaning that the better transformational leadership is executed, the more it will improve organizational performance. Likewise with organizational culture, it is proven that organizational culture affects organizational performance, meaning that the better the organizational culture is implemented, the more it can improve organizational performance.

The managerial implications that can be given from the results of this study should be that companies in implementing transformational leadership need openness and integration with other divisions so that increased performance is not only felt in one division but is integrated with other divisions. The theoretical implications for researchers who will be able to develop to examine other variables such as employee attitudes, coworkers, satisfaction, organizational environment, or others to obtain complete information related to the factors that affect performance.

\section{ACKNOWLEDGEMENT}

The authors greatly acknowledge the support from Sekolah Tinggi Manajemen STIMA IMMI Jakarta and Universitas Esa Unggul Jakarta Indonesia for providing the necessary resources to carry out this research work. The authors are also grateful to the anonymous reviewers and journal editorial board for their many insightful comments, which have significantly improved this article

\section{REFERENCES}

Ahmad Hariri, Supari Muslim, Eppy Yundra, Prasetyo Iswahyudi (2021) Using CIPPO Model to Evaluate Community Empowerment Education and Training Programs: A Case Study in East Java. Elementary Education Online, 20 (5), 10831088. doi:10.17051/ilkonline.2021.05.117

Ahmad Hariri, Dimas Haricahyo, Arief Rusdiansyah, \& M. Akbar Fathafirza. (2021). Effect of Work Knowledge on Competence of Cadets at Indonesian Aviation Academy Banyuwangi . SKYHAWK : Jurnal Aviasi Indonesia, 1(1), 48-51. Retrieved from http://ejournal.icpa-

banyuwangi.ac.id/index.php/skyhawk/article /view/9

Afen Sena, Ahmad Hariri, Genny Luhung Prasojo, \& Prasetyo Iswahyudi. (2021). Diplomacy Review of Delegation of Republic of Indonesia to the International Civil Aviation Organization in Montreal Canada. SKYHAWK : Jurnal Aviasi Indonesia, 1(1), 52-66. https://doi.org/10.52074/skyhawk.v1i1.10

Ardana, komang; Mujiati, Ni Wayan; Ayu Sriathi, Anak Agung. 2008. Perilaku Keorganisasian. Yogyakarta : Graha ilmu.

Ardiliscahyani, Putri. 2008. Pengaruh Budaya Organisasi Terhadap Komitmen Organisasi pada Karyawan di PT. Hutama Karya Wilayah IV Semarang. Penelitian Unnes Semarang

As'ad, Mohammad. 1987. Kepemimpinan yang Efektif dalam Perusahaan. Edisi Pertama. Liberty. Yogyakarta.

Gustina Amran, Tiena. 2007. Leadership and Organizational Culture Relationship Analysis On Job Performance and Satisfaction Using SEM(Structural Equation Modelling) At PT. Carita Boat Indonesia. Industrial Engineering Department, Trisakti University. 
Ghozali, Imam. 2009. Aplikasi Analisis Multivariate dengan Program SPSS. Semarang: Badan Penerbit Universitas Diponegoro.

Handoko, T. Hani. 2001. Manajemen Edisi 2. Yogyakarta : BPFE

Heri Sudarmaji, Genny Luhung Prasojo, Gatut Rubiono, \& Rifki Arif. (2021). Pendidikan Vokasi Aviasi: Peluang dan Tantangan. SKYHAWK : Jurnal Aviasi Indonesia, 1(1), 1-6. https://doi.org/10.52074/skyhawk.v1i1.1

Handrio Endo Martono, Ridho Rinaldi, Ahmad Mubarok, Rangga Handika Putra, \& Jadon Pieter Elia Tirtanto. (2021). Pendidikan Dasar Penerbang (Pilot) Dalam Lingkup Pendidikan Tinggi Vokasi. SKYHAWK : Jurnal Aviasi Indonesia, 1(1), 14-20. https://doi.org/10.52074/skyhawk.v1i1.4

Mangkunegara, A. Prabu. 2005. Manajemen Sumber Daya Manusia Perusahaan, Bandung:PT. Remaja Rosdakarya.

Mangkuprawira, Sjafri dan Arda Vitayala Hubeis. 2007. Manajemen Mutu Sumber Daya Manusia. Cetakan Pertama. Ghalia Indonesia.

Nurjanah. 2008.Pengaruh Gaya Kepemimpinan dan Budaya Organisasi Terhadap Komitmen Organisasi Dalam Meningkatkan Kinerja Karyawan (Studi Pada Biro Lingkup Departemen Pertanian). Tesis Undip Semarang.

Prasetyo Iswahyudi, Dewie, T. W., Soedjarwo, S., \& Hartono, S. (2019). Influence of Graduation Quality and Flight Training as a Vocational School on International Standard Job Opportunities. TEM Journal, 8(4), 1456.

Prasetyo Iswahyudi, Sabam Danny Sulung, Dimas Haricahyo, \& Handrio Endo Martono. (2021). Pengaruh Intelegence Quotient (IQ), Emotional Quotient (EQ) dan Spiritual Quotient (SQ) Terhadap Prestasi Belajar Mata Kuliah Pendidikan Pancasila pada Taruna Diploma III Penerbang Sayap Tetap Angkatan I Di Akademi Penerbang Indonesia Banyuwangi. SKYHAWK : Jurnal Aviasi Indonesia, 1(1), 7-13. Retrieved from http://ejournal.icpa-

banyuwangi.ac.id/index.php/skyhawk/article /view/3

Rivai, Veithzal. 2004. Manajemen Sumber Daya Manusia untuk Perusahaan: Dari Teori ke Praktik. Jakarta: PT. Raja Grafindo Persada.

Roby Muharomansyah, Ahmad Mubarok, Ridho Rinaldi, Syauqi M Fadillah, \& Nadila Nurchaliza. (2021). Pengaruh Kompetensi Flight Instructor Terhadap Siswa Penerbang: Studi Ex Post Facto. SKYHAWK: Jurnal Aviasi Indonesia, 1(1), 21-28.

https://doi.org/10.52074/skyhawk.v1i1.5

Rokhmawati, Puspita. 2008. Pengaruh Kepemimpinan dan Budaya Organisasi
Terhadap Kinerja Karyawan Unit Spinning Pada PT. Sinar Pantja Djaja di Semarang. Penelitian Unnes Semarang

Slamet, Achmad. 2009. Manajemen Sumber Daya Manusia. Semarang: Universitas Negeri Semarang Press.

Sopiah. 2008.Perilaku Organisasi. Yogyakarta : ANDI

Stefanus Kaihatu, Thomas. 2007. Kepemimpinan Transformasional dan Pengaruhnya Terhadap Kepuasan atas Kualitas Kehidupan Kerja, Komitmen Organisasi, dan Perilaku Ekstra Peran: Studi pada GuruGuru SMU di Kota Surabaya. Jurnal Ekonomi Manajemen, Universitas Kristen Petra.

Suprianti, Dwi. 2008. Pengaruh Kepemimpinan Transformasional dan Transaksional Terhadap Komitmen Organisasi Pada PT. Kereta Api Indonesia (Persero) DAOP IV Semarang. Penelitian Unnes

Sulistianto, Eko. 2009. Pengaruh Budaya Orgnaisasi, Gaya Kepemimpinan, Serta Kompensasi Terhadap Komitmen Organisasi Pegawai Dinas Perindustrian dan Perdagangan Jawa Tengah. Penelitian Unnes Semarang

Stephen, P. Robbins. 1996. Perilaku Organisasi: Konsep, Kontroversi, Aplikasi. Jilid kelima. Edisi Bahasa Indonesia. Jakarta: PT. Prenhalindo

Stephen, P. Robbins. 2006. Perilaku Organisasi. Edisi Kesepuluh. Jakarta: PT. Indeks.

Umar, Husein. 2003. Metode Riset Perilaku Organisasi. Jakarta : Gramedia Pustaka Utama. Wibowo. 2006. Manajemen Perubahan. Jakarta: Rajagrafindo Persada.

Yueh Chen, Li. 2004. Examining the Effect of Organization Culture and Leadership Behaviors on Organizational Commitment, Job Satisfaction, and Job Performance at Small and Middle-size Firms of Taiwan. The Journal of American Academy of Business. Cambridge. 